\title{
Semirigid penile prosthesis: technique and review of literature
}

\author{
Garrick M. Greear, Fady M. Ghali, Tung-Chin Hsieh \\ Department of Urology, University of California San Diego, La Jolla, CA, USA \\ Contributions: (I) Conception and design: All authors; (II) Administrative support: None; (III) Provision of study materials or patients: TC Hsieh; \\ (IV) Collection and assembly of data: All authors; (V) Data analysis and interpretation: All authors; (VI) Manuscript writing: All authors; (VII) Final \\ approval of manuscript: All authors. \\ Correspondence to: Tung-Chin Hsieh, MD. Department of Urology, 200 W Arbor Dr \# 8220, San Diego, CA 92103, USA. Email: t7hsieh@ucsd.edu.
}

\begin{abstract}
Since the development and popularization of the malleable semirigid device in 1973, penile prosthetic surgery has played a critical role in the management of end-stage erectile dysfunction. Several prostheses have come into use, most broadly categorized into semirigid penile prosthesis (SRPP) and inflatable penile prosthesis (IPP). In recent decades, SRPP use has declined with the advent of IPP, though there are still clinical settings for which this technique is most appropriate. We present a brief review of the indications, perioperative practices, and our surgical technique for SRPP implantation as well as a review of complications and device reliability.
\end{abstract}

Keywords: Penile prosthesis; semirigid; erectile dysfunction; Peyronie's disease

Received: 02 April 2019; Accepted: 28 October 2019; Published: 05 April 2020.

doi: 10.21037 /jovs.2019.11.07

View this article at: http://dx.doi.org/10.21037/jovs.2019.11.07

\section{Introduction}

First described in 1973, malleable penile prosthetics were quickly established as important therapeutic options for both erectile dysfunction, Peyronie's disease, and other pathologies $(1,2)$. Penile prosthetics are made by several manufacturers and can be categorized as semirigid penile prosthesis (SRPP) and inflatable penile prosthesis (IPP). Several important indications exist for the use of SRPP. Erectile dysfunction (ED) or Peyronie's disease have long been the most common indications for penile prosthetic implantation. In the era of oral phosphodiesterase type-5 inhibitors, the penile prosthesis is often reserved for men with medically refractory ED (3-5). SRPP may be particularly useful for men who have limited dexterity that might prevent them from pump operation of IPP, which has the advantage of being able to cycle through an erect and flaccid state mimicking normal physiology.

Recurrent priapism, or priapism refractory to conservative measures, can also safely be treated with corporal dilation and IPP/SRPP insertion (6). Another important indication for SRPP insertion is in the setting of salvage of penile prosthesis infection, though careful patient selection is essential (7). Long-term infection free rates up to $93 \%$ have been reported in the salvage setting $(8,9)$. Finally, SRPPs have played an important role in the quality of life improvement in men with neurologic impairment and urinary incontinence. Reflex penile retraction can make condom catheter fitting untenable and SRPP insertion can provide adequate penile body to affix the condom urinal (8).

\section{Perioperative antibiotic practices}

Device infection is a feared complication of prosthetics surgery, and there is no universal consensus on optimal antibiotic practices in the setting of penile prosthesis insertion. The American Urologic Association Best Practice Statement on antimicrobial prophylaxis recommends the use of an aminoglycoside and a 1 st or 2 nd generation cephalosporin or vancomycin for 24 hours (9). Our practice is to administer perioperative intravenous vancomycin and piperacillin-tazobactam for 24 hours. The prosthetic is bathed in a bacitracin antibiotic solution. Post-operative prophylaxis with oral trimethoprim/sulfamethoxazole is given for 7 days. Emerging literature suggests antifungal coverage might be necessary in certain high-risk settings (10). 


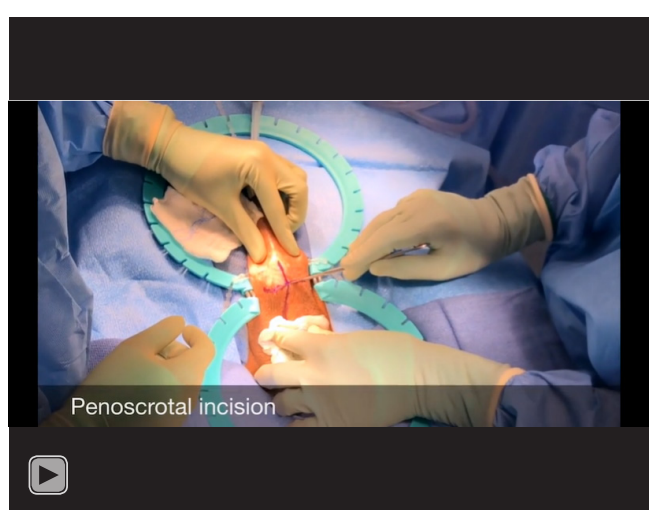

Video 1 Semirigid penile prosthesis (11).

\section{Surgical technique}

A penoscrotal approach is taken. This is distinctly advantageous in obese patients and greatly simplifies the operation by excellent exposure of the corporal and urethral anatomy. Placement of a urethral catheter facilitates preservation of the corpus spongiosum during dissection. A horizontal incision is made just below the penoscrotal junction. Dissection is carried through the dartos fascia to expose the corpora cavernosa on either side. Sutures (2-0 PDS) are pre-placed and vertical corporotomies made symmetrically on each side. Metzenbaum scissors are used to start the corporal dissection and establish a tract in the corporal tissue proximally and distally. Dilation is performed with the Dilamezinsert device before the corpora are sized. It is important to undersize by about 0.5 to $1 \mathrm{~cm}$ to avoid erosion from constant distal pressure within the glans. The implant is prepared on the back table after soaking in bacitracin antibiotic solution. After insertion of the prosthesis the corporotomies are closed with 2-0 delayed absorbable monofilament suture. An instructional video has been prepared to demonstrate our approach (Video 1).

\section{Outcomes}

Patients report high satisfaction rates after penile prosthesis surgery, regardless of semirigid or inflatable type (12). Rates of complications are generally low: hematoma $(0.2-3.6 \%)(13)$, floppy glans $(0.2-0.9 \%)$ (14), urethral injury (0.1-4\%) (15), vascular, bladder, bowel injury (rare) (15). The rate of infection with virgin implantation varies in the literature between $<1 \%$ to $4 \%$, with multiple factors likely at play (16). Modern infection rates tend to fall at the lower end of the spectrum.
There is evidence of an increased risk of infection in spinal cord injury patients, those on long term steroids, and smokers. The increased risk in diabetics is controversial (17). Revision implantation is known to have a higher risk of infection, up to $13.3 \%$ (18). Infection risk is highest in the peri-operative period, but can occur at any time. Gram positive organisms are the most common isolates in early prosthetic infections and are likely indicative of contamination by skin flora, while late infections tend to be gram negative organisms thought to be contracted by hematogenous seeding (19).

\section{Revision}

There have been no significant differences reported in revision rates of semi-rigid devices and inflatable prostheses (13). Recent long-term data suggest 5- and 10-year device survival rates of $88.8 \%$ and $84.3 \%$ respectively (14). Pain, infection, mechanical failure, and overall dissatisfaction are all possible indications for revision or device removal. A limitation common to most studies of device revision rates is that the indication for removal/revision is often not reported.

\section{Conclusions}

The SRPP is an important therapeutic option in the treatment of erectile dysfunction. Placement of a semirigid prosthesis via a penoscrotal incision is a straightforward procedure with a low risk of complications, comparable rates of patient satisfaction with IPP, and important tool for salvage protocols.

\section{Acknowledgments}

Funding: None.

\section{Footnote}

Provenance and Peer Review: This article was commissioned by the Guest Editors (Martin Gross, Jay Simhan and Faysal A. Yafi) for the series "Penile Prosthesis Surgery" published in fournal of Visualized Surgery. The article has undergone external peer review.

Conflicts of Interest: The series "Penile Prosthesis Surgery" was commissioned by the editorial office without any funding or sponsorship. TCH is a consultant for Endo Pharmaceuticals. The authors have no other conflicts of 
interest to declare.

Ethical Statement: The authors are accountable for all aspects of the work in ensuring that questions related to the accuracy or integrity of any part of the work are appropriately investigated and resolved. All procedures performed in this study were in accordance with the Helsinki Declaration (as revised in 2013). The manuscript is waived from patient informed consent according to the ethics committee or institutional review board.

Open Access Statement: This is an Open Access article distributed in accordance with the Creative Commons Attribution-NonCommercial-NoDerivs 4.0 International License (CC BY-NC-ND 4.0), which permits the noncommercial replication and distribution of the article with the strict proviso that no changes or edits are made and the original work is properly cited (including links to both the formal publication through the relevant DOI and the license). See: https://creativecommons.org/licenses/by-nc-nd/4.0/.

\section{References}

1. Mulcahy JJ. The Development of Modern Penile Implants. Sex Med Rev 2016;4:177-89.

2. Small MP, Carrion HM, Gordon JA. Small-Carrion penile prosthesis: New implant for management of impotence. Urology 1975;5:479-86.

3. Lee DJ, Najari BB, Davison WL, et al. Trends in the Utilization of Penile Prostheses in the Treatment of Erectile Dysfunction in the United States. J Sex Med 2015;12:1638-45.

4. Burnett AL, Nehra A, Breau RH, et al. Erectile Dysfunction: AUA Guideline. J Urol 2018;200:633-41.

5. Nehra A, Alterowitz R, Culkin DJ, et al. Peyronie's Disease: AUA Guideline. J Urol 2015;194:745-53.

6. Yücel ÖB, Pazır Y, Kadığlu A. Penile Prosthesis Implantation in Priapism. Sex Med Rev 2018;6:310-8.

7. Mulcahy JJ. Treatment alternatives for the infected penile implant. Int J Impot Res 2003;15 Suppl 5:S147-9.

doi: 10.21037 /jovs.2019.11.07

Cite this article as: Greear GM, Ghali FM, Hsieh TC. Semirigid penile prosthesis: technique and review of literature. J Vis Surg 2020;6:17.
8. Zermann DH, Kutzenberger J, Sauerwein D, et al. Penile Prosthetic Surgery in Neurologically Impaired Patients: Long-Term Followup. J Urol 2006;175:1041-4.

9. Wolf JS, Bennett CJ, Dmochowski RR, et al. Best Practice Policy Statement on Urologic Surgery Antimicrobial Prophylaxis. J Urol 2008;179:1379-90.

10. Gross MS, Phillips EA, Carrasquillo RJ, et al. Multicenter Investigation of the Micro-Organisms Involved in Penile Prosthesis Infection: An Analysis of the Efficacy of the AUA and EAU Guidelines for Penile Prosthesis Prophylaxis. J Sex Med 2017;14:455-63.

11. Greear GM, Ghali FM, Hsieh TC. Semirigid penile prosthesis. Asvide 2020;7:037. Available online: http:// www.asvide.com/watch/33077

12. Habous M, Tealab A, Farag M, et al. Malleable Penile Implant Is an Effective Therapeutic Option in Men With Peyronie's Disease and Erectile Dysfunction. Sex Med 2018;6:24-9.

13. Grewal S, Vetter J, Brandes SB, et al. A population-based analysis of contemporary rates of reoperation for penile prosthesis procedures. Urology 2014;84:112-6.

14. Mirheydar H, Zhou T, Chang DC, et al. Reoperation Rates for Penile Prosthetic Surgery. J Sex Med 2016;13:129-33.

15. Dick B, Tsambarlis P, Reddy A, et al. An update on: Longterm outcomes of penile prostheses for the treatment of erectile dysfunction. Expert Rev Med Devices 2019;16:281-6.

16. Narang GL, Figler BD, Coward RM. Preoperative counseling and expectation management for inflatable penile prosthesis implantation. Transl Androl Urol 2017;6:S869-S880.

17. Christodoulidou M, Pearce I. Infection of Penile Prostheses in Patients with Diabetes Mellitus. Surg Infect (Larchmt) 2016;17:2-8.

18. Jarow JP. Risk factors for penile prosthetic infection. J Urol 1996;156:402-4.

19. Mohajer Al M, Darouiche RO. Infections Associated with Inflatable Penile Prostheses. Sex Med Rev 2014;2:134-40. 